\title{
Design and Modeling of Wind Fed Resonant DC-DC Converter through Synchronous Generator using MATLAB/Simulink
}

\author{
S.Balakumar \\ Department of EEE \\ Annamalai university \\ Tamilnadu, India
}

\author{
B.Baskaran \\ prof, Department of EEE \\ Annamalai university \\ Tamilnadu, India
}

\begin{abstract}
This study presents the design, modelling and simulation of variable speed wind turbine through the LCL type DC-DC resonant converter for grid connected wind energy system using MATLAB/Simulink. Owing to enhancing the power demand and environmental issues, power generation from renewable energy is getting more consideration. The designed converter has main merits like reduced switching loss using soft switching methods, reduced transformer size, and filter size. In addition, this paper investigates the resonant converter application to obtain a constant D.C voltage at the output of the designed converter, reduced stress, EMI, and high power density. In this paper, fuzzy logic controller (FLC) is used to regulate the output voltage of resonant converter in comparison with PI controller. The simulation has been done in MATLAB/Simulink frame work. It is shown that a resonant converter enhances voltage profile of power grid containing synchronous generator based wind system.
\end{abstract}

\section{Keywords}

Resonant converter, synchronous generator, fuzzy logic controller, MATLAB/Simulink.

\section{INTRODUCTION}

Wind is one of the richest renewable sources of energy in natural history. The economical and environmental advantages offered by wind energy are the most key reasons why electrical systems based on wind energy are receiving vast global attention. Due to the increasing demand on electrical energy, a significant amount of effort is being made to generate electricity from harmless renewable energies.

Small-scale stand alone wind energy is increasingly viewed as a viable and occasionally preferred source of electrical energy; consider, for example, remote villages or ranches located far away from main power lines. Wind energy is a quiet option to remote diesel generation-generation that sometimes depends on excessive transportation and fuel storage costs-and an economically justifiable alternative to a grid connection. The need to integrate the renewable energy like wind energy into power system is to make it possible to minimize the environment impact on conventional plant has been well executed in [2].
There has been a wide growth and rapid development in the utilization of wind energy in recent years. The individual units can be of large capacity up to $2 \mathrm{MW}$, feeding into distribution network, predominantly with customers connected in close proximity was presented in [3]. A typical, small-scale, stand-alone, wind electric system consists of a wind turbine, a permanent-magnet generator, a diode bridge rectifier, and a dc power system. In many small- scale systems, the dc system is at a constant dc voltage and is usually comprised of a battery bank, allowing energy storage; a controller to keep the batteries from overcharging; and a load. The load may be dc or may include an inverter to an ac system has been addressed in [1]. Today, more than 28,000 wind generating turbines are successfully operating all over the world. Fluctuations in the wind speed are transmitted as fluctuations in the mechanical torque, electrical power on the grid and leads to large voltage fluctuations. Fluctuations in network, such as voltage sag, swells, flickers, harmonics etc has been discussed in [4]. From the literature reviews, it is clearly observed that the simulation of fuzzy logic control of $\mathrm{dc}$ to $\mathrm{dc}$ resonant converter using wind model has not been implemented in [5] [14]. Therefore, in this paper, it is proposed to design the simulation of fuzzy controlled dc to dc converter wind system modeling. The DC-DC resonant converter with fuzzy logic controller that achieves high wind turbine efficiency across a wide range of wind speeds. The system is designed for use in remote locations and therefore, includes a simple fuzzy logic control strategy and a fault tolerant topology. This paper mainly focuses on simulation of closed loop controlled DCDC converter with wind system modeling.

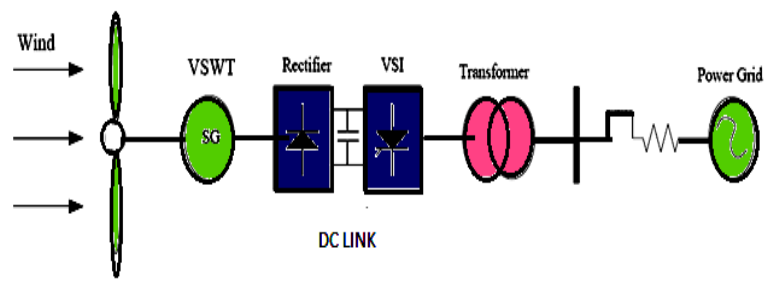

Fig.1.Schematic representation of modeled VSWT coupled synchronous generator. 
The schematic diagram of variable speed wind turbine (VSWT) model is shown in Fig. 1 and Fig.2.

Table 1. Specification of wind energy system data

\begin{tabular}{|l|l|}
\hline Effective turbine radius & $1.0 \mathrm{~m}$ \\
\hline $\begin{array}{l}\text { phase to phase winding } \\
\text { inductance }\end{array}$ & $3.3 \mathrm{mH}$ \\
\hline $\begin{array}{l}\text { Phase to phase winding } \\
\text { resistance }\end{array}$ & $0.71 \mathrm{Nm} / \mathrm{A}$ \\
\hline Poles & 8 \\
\hline System inertia & $1.2 \mathrm{~kg} \mathrm{\textrm {m } ^ { 2 }}$ \\
\hline System damping & $0.16 \mathrm{Nm} / \mathrm{k}$ \\
\hline
\end{tabular}

Table.2. Specifications of generator, transformer and converter data

\begin{tabular}{|c|}
\hline Synchronous generator \\
\hline Nominal power:1.5 MVA \\
\hline Line to line voltage: $600 \mathrm{v}$ \\
\hline $\begin{array}{c}\text { Reactance }\left(\mathrm{x}_{\mathrm{d}}=1.305, \mathrm{x}_{\mathrm{d}}=0.296, \mathrm{x}_{\mathrm{d}}^{\prime \prime}=0.252, \mathrm{x}_{\mathrm{q}}=0.474, \mathrm{x}_{\mathrm{q}}=0.243,\right. \\
\mathrm{xl}=0.18)\end{array}$ \\
\hline Stator resistance $\left(\mathrm{R}_{\mathrm{s}}\right): 0.00285 \mathrm{ohms}$ \\
\hline 3-phase transformer:1.5MVA, $0.6 \mathrm{kv} / 48 \mathrm{v}$ \\
\hline Transformer \\
\hline Nominal power:300v \\
\hline Winding $_{1}: 48 \mathrm{v}, \mathrm{R}_{1}=0.02 \mathrm{ohms}, \mathrm{L}=0.001 \mathrm{H}$ \\
\hline Winding $_{2}: 11.68 \mathrm{v}, \mathrm{R}_{1}=0.02 \mathrm{ohms}, \mathrm{L}=0.001 \mathrm{H}$ \\
\hline $\begin{array}{l}\text { Magnetization resistance\& inductance: } \\
\left(\mathrm{R}_{\mathrm{m}}\right)=500 \mathrm{ohms}, \mathrm{L}_{\mathrm{m}}=500 \mathrm{H}\end{array}$ \\
\hline Converter \\
\hline $\begin{array}{l}\text { Diode resistance }\left(D_{1}\right)=0.001, \text { FWD voltage }=0.8 \mathrm{v}, \text { snubber } \\
\text { resistance }\left(\mathrm{R}_{\mathrm{s}}\right)=5000 \mathrm{ohms} .\end{array}$ \\
\hline MOSFET \\
\hline FET Resistance :0.1ohms \\
\hline Internal diode resistance $\mathrm{R}_{\mathrm{d}}=0.01 \mathrm{ohms}$ \\
\hline Snubber resistance $\mathrm{R}_{\mathrm{S}}=100000 \mathrm{ohms}$ \\
\hline
\end{tabular}

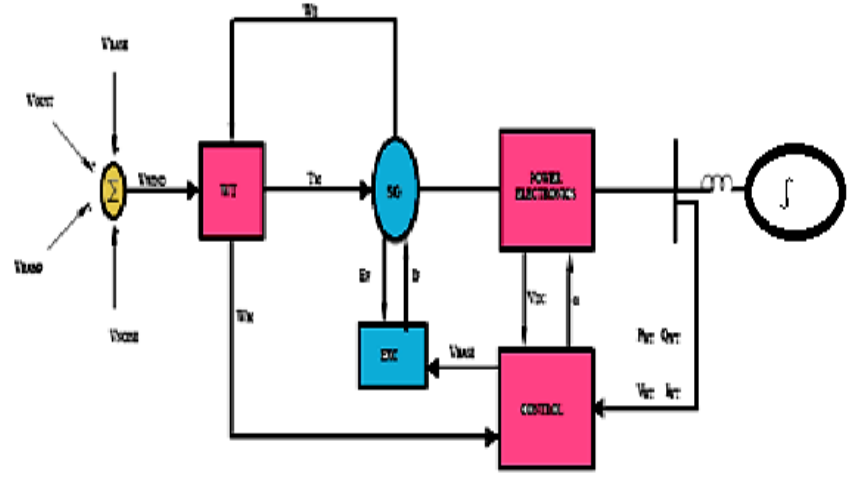

Fig.2. MATLAB/Simulink simulation model of a VSWT coupled Synchronous generator.

\section{THEORITICAL ANALYSIS}

The essential objective of utilizing a wind turbine is to convert the kinetic energy into mechanical energy, which can be applied to drive the shaft of an electrical power captured from the wind into electrical power. The power captured from the wind $\mathrm{P}_{\mathrm{w}}$ can be designed from [5]-[6].

$$
p_{w}=\frac{1}{2} \rho c_{p} A V_{w}^{3}
$$

Where,

$p_{w}$ is turbine power,

$\rho$ is the air density in $\mathrm{kg} / \mathrm{m}^{3}$,

$c_{p}$ is the power coefficient,

A is the wind turbine rotor swept area in $\mathrm{m}^{2}$,

and $v_{w}$ is the wind speed in $\mathrm{m} / \mathrm{s}$.

The mechanical power $p_{m}$ produced by the wind turbine due to $p_{w}$ depends on the power co-efficient $c_{p}$ of the wind turbine and can be expressed as.

$$
p_{m}=c_{p}(\lambda, \beta) p_{w}
$$

The co-efficient of performance is a function of Tip speed ratio (TSR) and is given by

$$
T S R=\frac{{ }_{\omega}}{V_{\omega}}
$$


Where

$$
\begin{aligned}
\omega_{m} & : \text { Rotational speed } \\
\gamma & : \text { Turbine } \\
V_{\omega} & : \text { Wind speed }
\end{aligned}
$$

A typical curve is shown in fig (3). The maximum power captured by the wind turbine will occur when the TSR is approximately 7.5 , corresponding to a $\mathrm{C}_{\mathrm{P}}$ Of 0.35 .

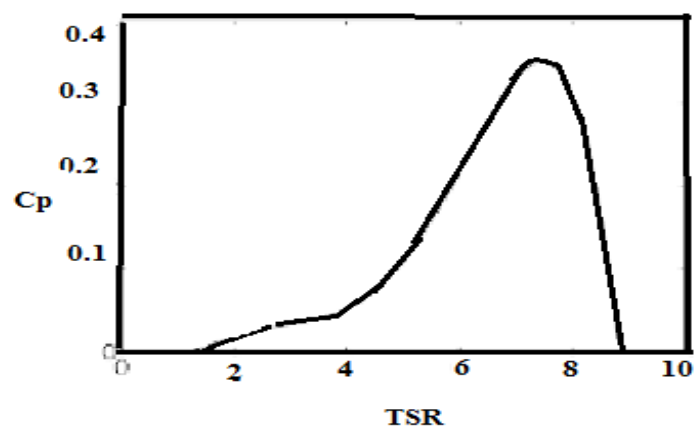

Fig 3. Typical $C_{p}$ curve.

The VSWT model consists of the following components; they are

- Wind model

- Wind turbine and control

- Synchronous generator

- Rectifier and inverter

\subsection{Wind model}

A wind model selected for this study is contains four components [15], and can be mathematically expressed as

$$
V_{W}=V_{B}+V_{G}+V_{R}+V_{N}
$$

Where

$\mathrm{V}_{\mathrm{B}}=$ base wind speed component $(\mathrm{m} / \mathrm{s})$

$\mathrm{V}_{\mathrm{G}}=$ gust wind component $(\mathrm{m} / \mathrm{s})$

$\mathrm{V}_{\mathrm{R}}=$ ramp wind component $(\mathrm{m} / \mathrm{s})$

$\mathrm{V}_{\mathrm{N}}=$ Noise wind component $(\mathrm{m} / \mathrm{s})$

The base component is a stable speed and wind gust component can be usually expressed as a sine or cosine wave function. In this simulation, wind speed represent the constant block in MATLAB/Simulink.

\subsection{Design of wind turbine and control}

The wind turbine can be described by the following equations (5), (6), and (7) collectively.

$$
\lambda=\frac{\omega_{m} R}{V_{W I N D}}
$$

(5)

$$
P_{m}=\frac{1}{2} \rho \pi R^{2} C_{p} V_{W I N D}^{3}
$$

Eqn (5) gives :

$$
\begin{aligned}
& V_{W I N D}=\frac{\omega_{m} \cdot R}{\lambda} \\
& P_{m}=\frac{1}{2} \rho \pi R^{2} C_{p}\left(\frac{\omega_{m} \cdot R}{\lambda}\right)^{3} \\
& P_{m}=\frac{1}{2} \rho \pi R^{5} C_{p}\left(\frac{\omega_{m}}{\lambda}\right)^{3}
\end{aligned}
$$

$T_{m}=\frac{p_{m}}{\omega_{m}}$

Where $\lambda=$ tip speed ratio, $\mathrm{m}=$ blade angular speed [mechanical $\mathrm{rad} / \mathrm{s}], \quad \mathrm{R}=$ blade $\operatorname{radius}[\mathrm{m}], \quad \mathrm{V}_{\text {wind }}=$ wind $\operatorname{speed}[\mathrm{m} / \mathrm{s}]$, $\mathrm{P}_{\mathrm{m}}=$ mechanical power from wind blade[kw], $\rho=$ air density $\left[\mathrm{kg} / \mathrm{m}^{3}\right], \quad C_{P}=$ power co-efficient, $T_{m}=$ mechanical torque obtained from equation (9) is the input torque to the synchronous generator and is driving the generator. $\mathrm{C}_{\mathrm{p}}$ may be expressed as a function of the tip speed ratio (TSR) $\lambda$ is given by equation (2) [5].

$c_{p}=(0.44-0.0167 \beta) \sin \frac{\pi(\lambda-2)}{(13-0.3 \beta)}-0.00184(\lambda-2) \beta$

Where

$B$ is the blade pitch angle, for a fixed pitch type the value of $\beta$ is set to a constant value.

\subsection{Mathematical analysis of synchronous generator}

The MATLAB/ Simulink gives a fully designed and developed synchronous generator model, which is purely based on generalized machine theory [14] and with model both sub-transient and transient behavior of the system is clearly examined. This model is considered that the synchronous generator is equipped with an exciter identical to IEEE type 1 model [10]. 
The exciter can be adjusted to meet out dc link voltage requirement and also synchronous generator can be operating at different power factor. Since the generator is a direct drive type with low speed and a high number of poles, the wind turbine and the generator are rotating at the same mechanical speed via the same shaft. Therefore, shaft dynamics can be characterized by a swing equation on a single mass rotating shown in equation (9). The shaft dynamics and the rotating mass can be represented by multi-mass torsion shaft model of MATLAB/Simulink, which can be easily interfaced with synchronous machine model.

$$
J_{m} \frac{{ }^{d} \omega_{m}}{d t}=T_{m}-T_{E}-D_{\omega_{m}}
$$

Where

$\mathrm{J}_{\mathrm{m}=}$ a single rotating inertia $\left(\mathrm{k}_{\mathrm{g}}-\mathrm{m}^{2}\right)$

$\mathrm{T}_{\mathrm{E}=}$ electrical torque produced by generator $(\mathrm{N}-\mathrm{m})$.

$\mathrm{D}=$ damping $(\mathrm{J}-\mathrm{s} / \mathrm{rad})$.

In variable speed operation, the rotating speed of the wind generator is not consistent with the electrical synchronous speed of the electrical network and generally much slower. The electrical base frequency of the machine in the built in models must be set to a value corresponding to the rated mechanical speed of the wind turbine specified by a manufacturer or a designer. Equations (12) and (15) gives the value for the electrical base speed of the synchronous machine $\mathrm{W}_{\mathrm{B}}$.

$f_{B}=\frac{p}{2} \cdot \frac{R P M_{\text {TURBINE }}}{60}$

$\omega_{B}=2 \pi f_{B}$

$\omega_{B}=2 \pi\left(\frac{p}{2} \cdot \frac{R P M_{\text {TURBINE }}}{60}\right)$

$\omega_{B}=\pi \cdot \mathrm{p} \cdot \frac{R P M_{\text {TURBINE }}}{60}$

\section{SIMULATION RESULTS}

Simulation is performed by using MATLAB/Simulink and its model is indicated in Fig.4 and Fig. 5 with specifications is listed in Tables $1 \& 2$. The wind turbine model is coupled to the input side of the resonant DC-DC converter. The output waveform of wind turbine model fed AC-DC converter output is $48 \mathrm{~V}$, which is given as input to the DC-DC converter. Fig. 6 show the output voltage of resonant DC-DC converter using fuzzy logic controller in start-up region. From the result, it is clearly found that output voltage of the converter has no overshoot and quick settling time of $0.02 \mathrm{~s}$. The output waveform of wind turbine model fed AC-DC converter output is $48 \mathrm{~V}$, which is given as input to the DC-DC converter as depict in Fig.7. In Fig. 8 show the output voltage and wind velocity of designed model. From the figure, tit is observed that the output voltage of converter is independent of wind velocity. In order to access the capability of the system in tracking maximum power point at varying wind velocity, a step change in the wind velocity is applied to the system. The system is first operating at the wind velocity of $8 \mathrm{~m} / \mathrm{s}$. At this velocity, maximum output of converter is $12 \mathrm{v}$. At time of $0.1 \mathrm{sec}$, the wind velocity is changed to $10 \mathrm{~m} / \mathrm{s}$. The maximum output of converter corresponding to this velocity is $12 \mathrm{~V}$. The system output is free from ripple and peak overshoot. It gives constant output voltage compared with PI controller system. This fuzzy controller-based closed loop system is superior to the commonly used PI controllerbased closed loop control. Simulation results show successful tracking of maximum power from the wind at all wind velocities. The output voltage is sensed and it is compared with a reference voltage of $12 \mathrm{v}$. The error is given to a fuzzy logic controller. The output of fuzzy controller generates pulses with reduced width. When these pulses are applied to the MOSFET's in the output rectifier, the output reduces to the set value. Thus the closed loop system is capable of reducing the steady state error. The parameters of $\mathrm{k}_{\mathrm{p}}=4$ and $\mathrm{k}_{1}=0.1$ are used for simulation studies.

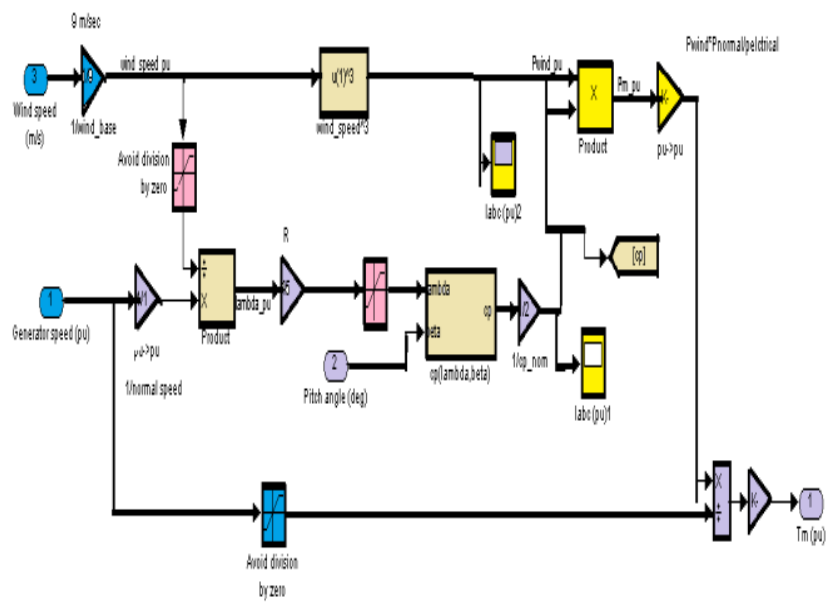

Fig .4. Wind turbine model. 


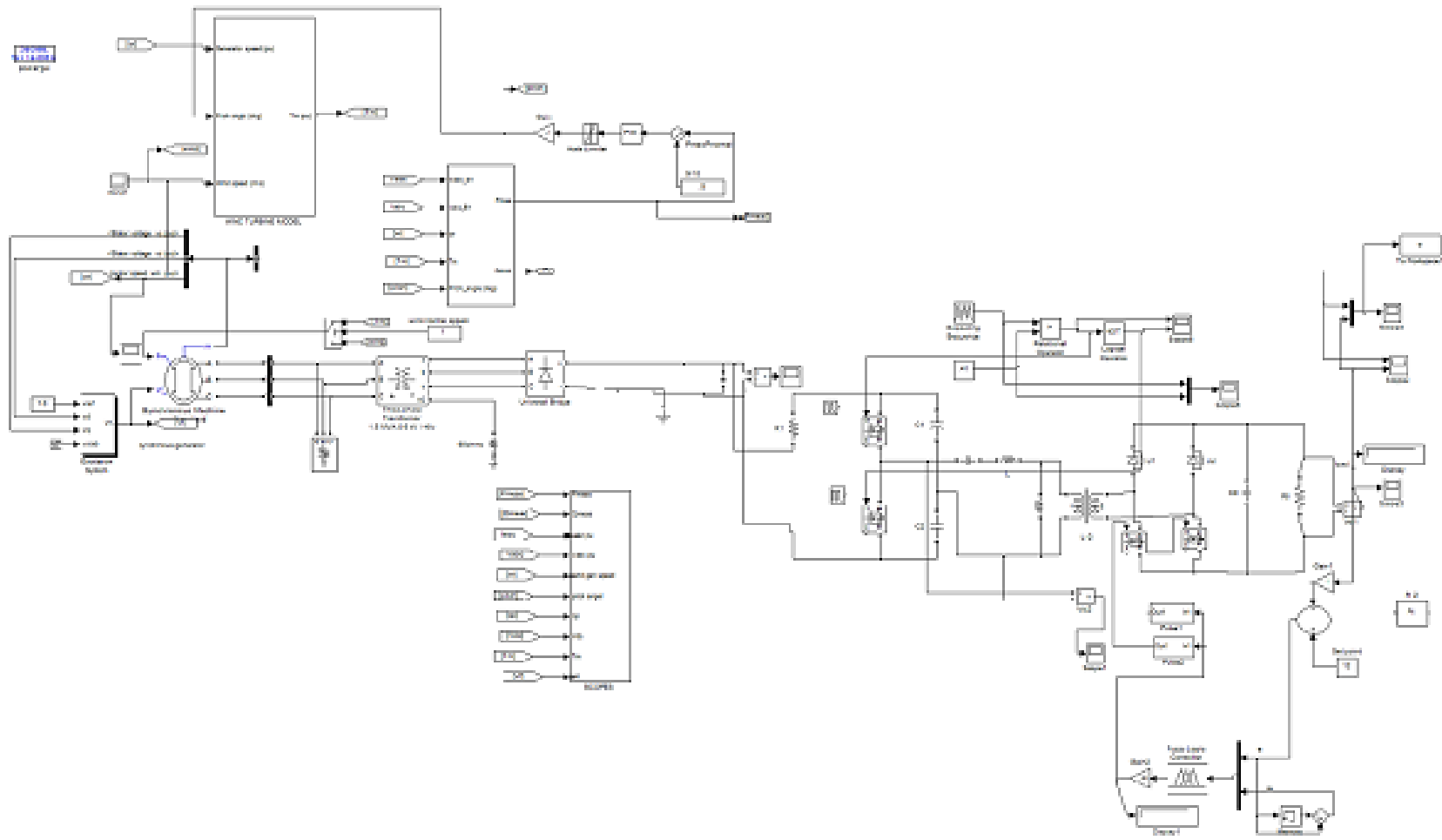

Fig .5. DC-DC Converter circuit with Wind Turbine model at Input side.

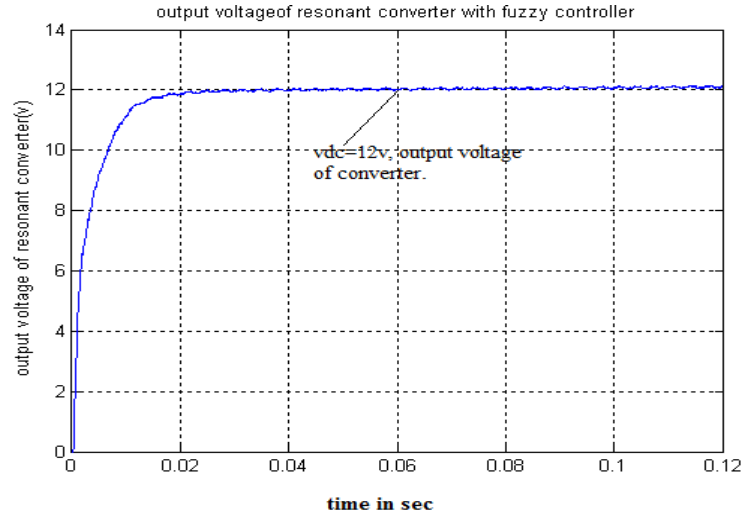

Fig.6. Output voltage of resonant converter with wind model using FLC.

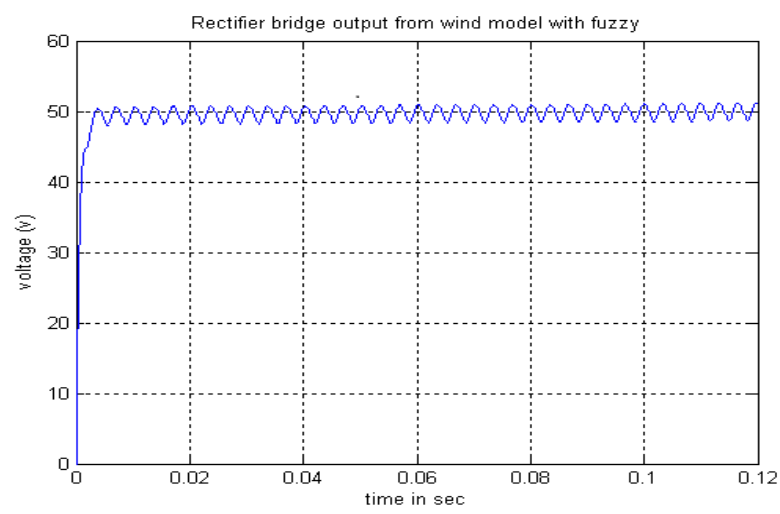

Fig.7. Output voltage of AC-DCc converter from wind model using FLC.

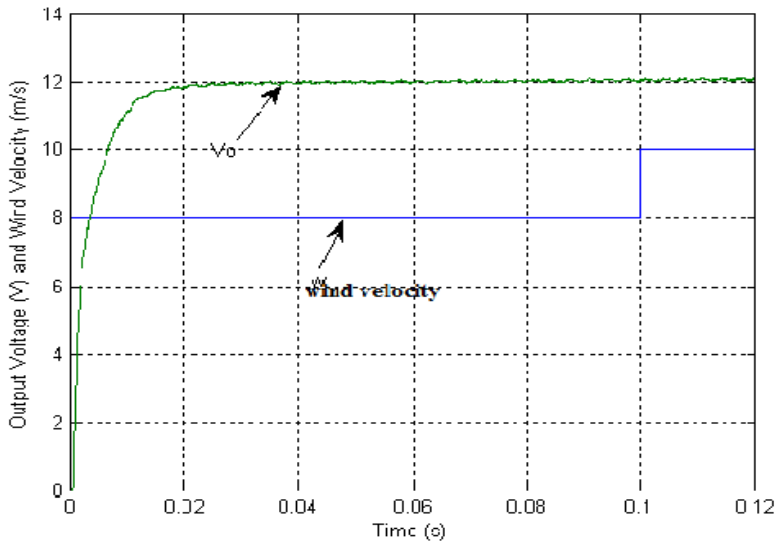

Fig.8. Output voltage of dc-dc converter using FLC with wind velocity.

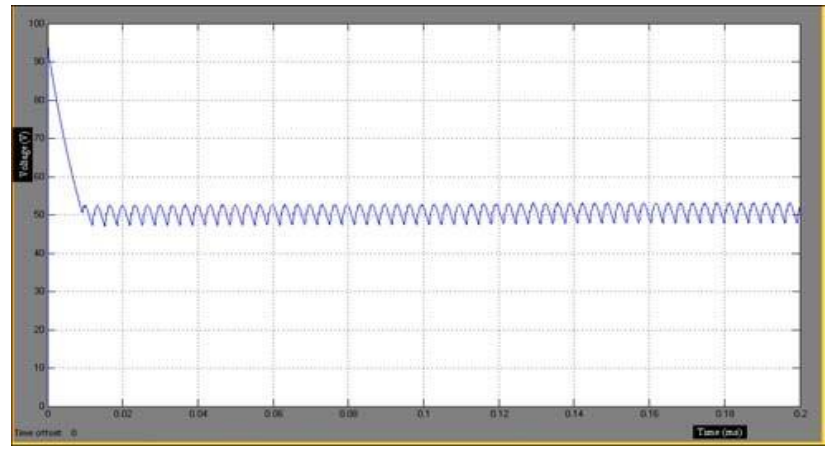

Fig.9.Output voltage of AC-DC converter from wind model using PI controller. 


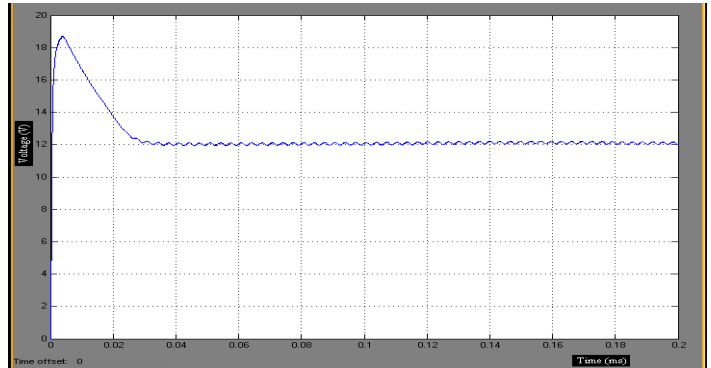

Fig.10. Output voltage of DC - DC converter using PI controller.

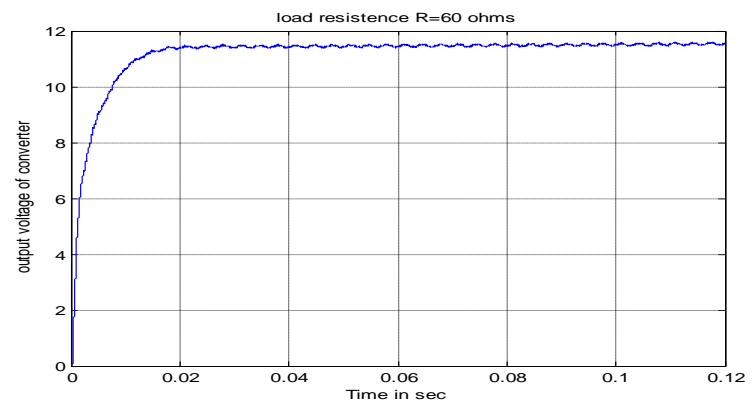

Fig.11. Output voltage of resonant converter using FLC with load resistance variation $R=60 \mathrm{ohms}$.

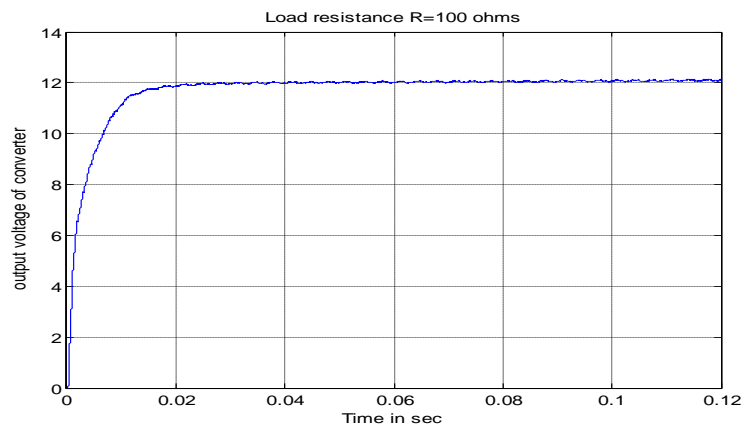

Fig.12. Output voltage of resonant converter using FLC with load resistance variation $R=100 \mathrm{ohms}$.

Figs. 9 and 10 shows the simulated results of output voltage of both AC-DC converter and resonant DC-DC converter using P.I and fuzzy controller. From the simulation results were showed more overshoot of $(45 \mathrm{~V}$ and $7 \mathrm{~V})$ and long settling time of $0.04 \mathrm{~s}$ respectively in case of P.I controller. The electrical performances of the converter have been analyzed by simulation runs. The output of converter is held constant irrespective of change in R-values. Figs. 11, and 12 shows the simulation result of converter using fuzzy logic controller at different load resistance of $60 \mathrm{ohms}$, and $100 \mathrm{ohms}$ has been presented clearly below in Figs. 11, and 12. In summary from the Fig.6 to Fig. 12, the simulation results of PI controller produced more overshoots and long settling time in comparison with fuzzy logic controller.

\section{CONCLUSIONS}

In this paper, design, modeling and simulation of fuzzy logic loop controlled DC-DC converter with grid connected wind generator has been successfully implemented in MATLAB/Simulink. In this paper, the LCL type DC-DC resonant converter was mastery in reduced EMI effect, stresses and high power density. The simulated results of designed controller with system were showed that successful tracking of maximum power from the wind at all wind velocities, good load voltage regulation of converter in comparison with PI controller has been obtained.

\section{REFERENCES}

[1] Annamalai. M, Dr. M. vijaya kumar, life fellow, ISTE, "Modeling and simulation of variable speed wind turbine with resonant DC-DC converter," International conference on power electronics, systems and Applications(ICPESA 2012) August 25-26,2012 kuala lumpur (Malaysia).

[2] A.sannino, "Global power systems for sustainable development ," In IEEE Generai meetig, Dener, CO, Jun.2004.

[3] R.Billinton and Y.Gao,"Energy conversion system models for adequancy assessment of generating systems incorporating wind energy," IEEE Trans.on E. Conv., vol.23, no.1,pp.163-169,2008,Multistate.

[4] Sharad W.Mohod Member, IEEE, and Mohan V.Aware,"A statcom-control scheme for grid connected wind energy system for power quality improvement", IEEE system journal, vol.4,No.3,September 2010.

[5] M.E.Haque, Negnevitsky, and K.M.Muttaqi, "A novel control strategy for a variable speed wind turbine with a permanent -magnet synchronous generator," IEEE Trans.Ind. Appl.,vol.46,no.l,pp331-339,Jan/Feb.2010.

[6] H.Geng, G.Yang, D.Xu. and B.Wu," unified power control for PMSG-based WECS operating under different grid conditions," IEEE Trans. Energy convers ., vol.26, no.3,pp.822-830,sep.2011.

[7] W.D.Kellogg, M.H.Nehrir, G.Venkataramanan, and V.Gerez, "Generation unit sizing and cost analysis for Stand-alone wind, photovoltaic, and hybrid wind/PV systems," IEEE Trans. Energy Conversion. Vol. 13, pp. 70-75, 1998.

[8] P.Chandrasekhar, S.Ramareddy "Optimum controlled Full Bridge LC resonant converter for Electrolyser Application ," proceeding of the World congress on Engineering and Computer Science pp.20-22,2009.

[9] S.H.Hosseni, R.Moradi, "A new active snubber cell for DC tO DC converter," IEEE Transaction on power electronics, pp 349-359,2008.

[10] M. Arutchelvi and S. Arul Daniel, "Voltage Control of autonomous hybrid generation scheme based on PV array and wind-driven induction generators", Electric power components and systems, pp. 759-773, Vol.34, No.7, July 2006.

[11] S.Arul Daniel and N.Ammasai Gounden "A novel Hybrid Isolated Generating System based on PV fed Inverter assisted Wind-driven Induction Generators". IEEE Transaction on energy conversion, pp 416- 422, Vol. 19, No.2, June 2004 
[12] M.Arutchelvi and S.Arul Daniel, "Composite controller for a hybrid power plant based on PV array fed wind driven induction generators," Electrical power components and systems, pp. 759-773, vol.34,No.7, July 2006.

[13] Ashoka K.S.Bhat,"Analysis and design of a seriousparallel resonant converter," IEEE Transactions on power electronics, vol.8.no.1, Jan 1993.
[14] S. Drouilhet, E. Muljadi, R. Holz, and V. Gevorgian, "Optimizing small wind turbine performance in battery charging applications," in NREL/TP-441-7808. Golden, CO: National Renewable Energy Laboratory, 1995.

[15] N. Yamamura, M. Ishida, and T. Hori, "Asimple wind power generatingsystem with permanent Magnet type synchronous generator," in Proc.IEEE Int. Conf. Power Electronics Drive Systems, vol. 2, Hong Kong, Jul. 27-29, 1999, pp. 849-854. 